China Perspectives

$2011 / 3$ | 2011

Chinese Medicine: The Global Influence of an Evolving Heritage

\title{
Chinese Medicine and the Enticement of Heritage Status
}

Frédéric Obringer

Translator. N. Jayaram

\section{OpenEdition}

Journals

\section{Electronic version}

URL: http://journals.openedition.org/chinaperspectives/5621

DOI: 10.4000/chinaperspectives.5621

ISSN: 1996-4617

\section{Publisher}

Centre d'étude français sur la Chine contemporaine

\section{Printed version}

Date of publication: 1 October 2011

Number of pages: 15-22

ISSN: 2070-3449

\section{Electronic reference}

Frédéric Obringer, «Chinese Medicine and the Enticement of Heritage Status », China Perspectives

[Online], 2011/3 | 2011, Online since 30 September 2014, connection on 28 October 2019. URL : http:// journals.openedition.org/chinaperspectives/5621; DOI : 10.4000/chinaperspectives.5621 


\title{
Chinese Medicine and the
}

\section{Enticement of Heritage Status}

\author{
FRÉDÉRIC OBRINGER*
}

\begin{abstract}
In November 2010, UNESCO included "Acupuncture and moxibustion as part of Chinese traditional medicine" on its Representative List of the Intangible Cultural Heritage of Humanity. Already in 2006, a national list of oral and intangible masterpieces of heritage was drawn up. Nine of them pertained to medicine and traditional pharmacopoeia. Since then, two other national lists have been compiled, containing medical elements. This article analyses the challenges of Chinese medicine's "patrimonialisation" by retracing the discipline's recent as well as much older history. Contents of different lists are examined in this perspective. Chinese medicine finds itself in a paradoxical situation, compared in practical terms with biomedicine, in perpetual reclassification, and held up for good or for bad reasons. Its inclusion in the cultural heritage list highlights many problematic issues, such as master-disciple transmission, vague teaching methods, questions as to the scientific nature or otherwise of its practices, and the industrialisation of its pharmacopoeia. In conclusion, questions may be raised over the link between protection and denaturation throughout the heritage designation process.
\end{abstract}

KEYWORDS: Chinese medicine, intangible cultural heritage, heritage designation.

n November 2010, UNESCO included "Acupuncture and moxibustion as part of Chinese traditional medicine" on its Representative List of the Intangible Cultural Heritage of Humanity. This article will consider the challenges of this "patrimonialisation" of Chinese medicine by going over the discipline's recent history. Chinese medicine (中医 - zhongyi) finds itself in a paradoxical situation, compared in practical terms with biomedicine, in perpetual reclassification, and held up for good or for bad reasons. Its inclusion in the cultural heritage list highlights several problematic issues. The "invention" of "Traditional Chinese Medicine" (TCM) has been underway for more than 50 years. But the ambivalent nature of teaching has affected its transmission from expert to apprentice, and questions are constantly raised regarding its scientific credentials as well as its clinical and therapeutic practices. At a time when acupuncture and Chinese pharmacopoeia are increasingly spreading in Europe, the Americas, and Africa, and thus form part of the circulation of knowledge and medical know-how their acquisition of heritage status marks a new stage in their ceaseless reconfiguration at both national and international levels. Many questions arise as to the definition of this medicine, its social and cultural construction, and its complex status in China and abroad. This article's main point will be an analysis of texts offered in the national list of masterpieces and submissions made to UNESCO for inclusion on its list.

\section{Chinese medicine's recent history, progress, and debates}

Chinese medicine as found in China now is the fruit of a long history, diverse political decisions, and a theoretical and practical reconstruction. (1) After having had an ambiguous status in communist China until Mao Zedong's death, it began to enjoy special attention and support from the Ministry of Health from 1980 onwards. Professionalisation of traditional practitioners was encouraged, and efforts were made (in 1982-1983) to define structures for teaching (in Chinese medicine institutions) and research (including in hospitals), with Chinese medicine being clearly distinguished from biomedicine. For the purpose of teaching, it was decided to club together a whole series of doctrines and therapeutic practices from previous eras drawn sometimes from different schools, but all of them carefully shorn of anything smacking too much of "superstition." In medical vocabulary, xiyi (西医 - "Western medicine") is set apart from zhongyi. The word "traditional" (传统 - chuantong) is hardly used in China, with the expressions "TCM" and "Traditional Chinese Medicine" being used outside the country or in Chinese publications meant for foreigners. (2)

The issue of Chinese medicine's validity and survival has been raised since the 1920s. Those favouring a modern public health system unsuccessfully put forward in 1929 a draft law to ban the teaching and practice of Chinese medicine. Intellectuals such as Guo Moruo and Lu Xun clubbed it with divination and such other "superstitions" of another age. After 1949, tension persisted between detractors of the system deemed irrational and supporters who held that the discipline represented national cultural heritage. (3) From 1950 to 1954, things did not go well for Chinese medicine, which, according to Wang Bin (王斌) represented "feudal society" (封建社会 - fengjian shehui). But from 1954 onwards Mao Zedong

Frédéric Obringer is CNRS researcher, Centre d'études sur la Chine moderne et contemporaine (Research Centre on Modern and Contemporary China), UMR 8173 (obringer@ehess.fr).

1. On Chinese medicine since 1949 , see for instance Volker Scheid, Contemporary Chinese Medicine, Plurality and Synthesis, Durham, Duke University Press, 2002; Kim Taylor, Chinese medicine in early communist China, 1945-1963: A medicine of revolution, London, New York, RoutledgeCurzon, 2005.

2. Volker Scheid, Contemporary Chinese Medicine, Plurality and Synthesis, op. cit., p. 3.

3. Kim Taylor, Chinese medicine in early communist China, 1945-1963: A medicine of revolution, op. cit, Wang Li, "La Convention pour la sauvegarde du patrimoine culturel immatériel et son application en droits français et chinois" (Convention to protect intangible cultural heritage and its application in French and Chinese law), public law thesis defended on 14 June 2010, Université Paris 11, (unpublished thesis, accessible in library), pp. 373 sq. 
showed more interest in it with the creation of a section for this medicine in the Health Ministry and then the setting up of a Chinese company to produce pharmaceuticals (中国药材公司 - Zhongguo yaocai gongsi) in March 1955. The first four universities of Chinese medicine opened in 1956 - at Beijing, Chengdu, Shanghai, and Guangzhou. The idea took shape around then of "unifying Chinese medicine and Western medicine" ( 中西 医结合 - Zhongxiyi jiehe), and then in 1958 came the famous slogan "Chinese medicine and pharmacology are a great treasure" (中国医药学是一个 伟大的宝库 - Zhongguo yiyaoxue shi yi ge weida de baoku). With this rose the notion of national "treasure."

In order to show the "scientificity" of Chinese medicine or at least its rational character, work was done on the process stretching from diagnostics to treatment. The concept of "bianzheng lunzhi" (辩证论治), (4) which may be rendered as "syndrome differentiation and discussion of treatments," was forged from 1950. Even though it can be easily shown that there is a continuity between this way of medical reasoning and the pre-1950 texts, the fact remains that the willingness to build from that time on a group of doctrines where the determination - amid the forest of clinical symptoms - of what constituted the real nature of the disease systematically accorded with the treatment adopted, seemed to be a new stage in the establishment henceforth of Chinese medicine as a competitor to "Western medicine."

From an administrative perspective, several decisions sealed the authorities' firm backing for Chinese medicine. For instance, it was included in $\mathrm{Ar}$ ticle 21 of the 1982 Constitution pertaining to health. In 1988 the National Bureau of Chinese Medicine and Pharmacology ( 中医药管理局 Zhongyiyao guanli ju) was established. In the $10^{\text {th }}$ Five Year Plan (20002005), it was decided to boost Chinese medicine's profile in health institutions. ${ }^{(5)}$ Notwithstanding this intention, there was a qualitative and quantitative deterioration. China Daily reported on 29 April 2009 that the number of doctors practising Western medicine stood at about 5.5 million, whereas there were just 400,000 TCM practitioners, or 20 percent fewer than 50 years earlier.

It was in this context that some elements of Chinese medicine practices were included in the national list of intangible heritage, before the acceptance of acupuncture and moxibustion on UNESCO's representative list. Alongside these developments, however, Chinese medicine's actual status in the country has remained fragile. It is threatened by internal factors to do with standardisation and the break in transmission of knowledge, as well as by external ones that question its legitimacy.

\section{Standardisation of teaching}

Standardisation has affected many domains. The gradual changes adopted in university teaching since 1956 have led to the replacement of the master-disciple model with selectivity in the materials handed down and an abandonment of the reading and study of medical classics in favour of manuals produced for the new regimen. (6) Students' intellectual achievements do not make for familiarity with ancient texts; in 1999, for instance, the common material for all university graduates was philosophy, contemporary Chinese, and English, but not classical Chinese. In 2008, it was estimated that among all courses for Chinese medicine students, the actual hours devoted to the discipline proper constituted just half of the total, the rest taken up by Western medicine courses and those common for all graduates. ${ }^{(7)}$

\section{Standardisation and industrialisation}

In Chinese medicine, prescriptions (方 - fang) must be adapted to the patient's idiosyncrasies. Using a basic formulation, the doctor juggles with dosages but also removes or adds one (most often) or many drugs in the composition, trying to best meet the individual characteristics of the pathological situation being dealt with. Such subtlety in the art of prescription becomes very difficult to apply when the doctor no longer has recourse to medicines prepared on the spot by the pharmacy or by the patient concerned, but has to rely on pharmaceutical industry products, which can only be of the standardised kind. This is what is known as manufactured drugs ( 中成药 - zhongchengyao) ready for consumption, which have since 1992 benefited from protective measures favouring industrialisation so long as they respond to various effectiveness criteria. ${ }^{(8)}$ One of the specificities demanded of Chinese medicine, namely individualisation of treatments, is thus called into question by the perhaps unavoidable transformation of the marketing of traditional medicines.

Since the 1990s and in the context of China's accession to the World Trade Organisation (WTO), it became imperative to conform to international standards (Good Agricultural Practices, GAP) in farm production conditions, including of plants forming raw material for pharmaceuticals. ${ }^{(9)}$ This led to the formulation of a document known as "Good Agricultural Practices for Chinese Crude Drugs" promulgated in 2003 by the Guojia shipin yaopin jiandu guanli ju (国家食品药品监督管理局 - State Food and Drug Administration ), containing 104 criteria for evaluation. They cover everything from farming environment, cultivation methods, and hygiene conditions to the qualification of personnel. Its application can only lead to the exclusion of small producers and, consequently, of the loss of traditional know-how. In 2004, in fact, 80 percent of the medicinal plants on the market came from private farmers lacking a vendor status. Moreover, the high financial cost of obtaining certification can only benefit big industrial producers. ${ }^{(10)}$ However well founded the quality expectations in farm production, this policy will reduce the diversity of plants used in Chinese medicine.

A similar phenomenon can be observed with regard to simple drugs (饮 片 - yinpian), ${ }^{(11)}$ that is, raw materials produced according to traditional methods of preparation, which are then used - often in combination ${ }^{(12)}$ to put together drugs in various galenic forms following a doctor's prescription. Good Manufacturing Practices (GMP) apply since 2003 to the

4. Volker Scheid, Contemporary Chinese Medicine, Plurality and Synthesis, op. cit., pp. 200 sq.

5. Wang Li, "La Convention pour la sauvegarde du patrimoine culturel immatériel et son application en droits français et chinois," op. cit., p. 390.

6. Volker Scheid, Contemporary Chinese Medicine, Plurality and Synthesis, op. cit., p. 75.

7. Wang Li, "La Convention pour la sauvegarde du patrimoine culturel immatériel et son application en droits français et chinois," op. cit., p. 407.

8. Zhongyao pinzhong baohu tiaoli 中药品种保护条例 (Regulations for protecting Chinese medicine varieties), State Council ordinance no. 106, 14 October 1992; see also Wang Li, "La Convention pour la sauvegarde du patrimoine culturel immatériel et son application en droits français et chinois," op. cit., p. 430.

9. Wang Li, "La Convention pour la sauvegarde du patrimoine culturel immatériel et son application en droits français et chinois," op. cit., p. 421, and www.globalgap.org, which evaluates Good Agricultural Practices.

10. Wang Li, "La Convention pour la sauvegarde du patrimoine culturel immatériel et son application en droits français et chinois," op. cit., p. 423.

11. The word "drug" is used in the sense of "natural ingredient for preparing medicines."

12. Chinese medicine in general uses several ingredients (often between five and ten) for a prescription, each ingredient having a specific role in the formulation. 
traditional medicine field and have become indispensable for market access since 2008. ${ }^{(13)}$ At the start of that year, a mere 200 of the 1,100 registered companies making drugs had obtained GMP certification. It is likely that many firms will disappear, lacking the economic means to obtain this certification.

\section{The issue of knowledge transmission}

The knowledge transmission model for Chinese medicine through universities has shown limitations, and attempts have been underway since the 1990s to reappraise the master-discipline (师徒传承 - Shitu chuancheng) teaching model. This is echoed in the major transmission system (living human treasure, discussed infra) for national elements of intangible cultural heritage. In 1990, as many as 462 "famous and veteran" practicians and 725 disciples were chosen, ${ }^{(14)}$ and in this way 2,200 students were trained between 1990 and 2005. However, it should be noted that many of these students had already been doctors.

In 1999, this situation was formalised with the Ministry of Health's decree introducing a master-apprentice transmission contract (师承关系合同 - shicheng guanxi hetong). An equivalent rating with university teaching became possible, following tests of knowledge. The teacher must be a doctor with more than 15 years of clinical practice. A standard contract was proposed in 2006. An evaluation is made at the end of three years, and successful candidates receive a certificate of aptitude in traditional medicine through the master-apprentice method. But it does not amount to the title of physician. ${ }^{155}$

\section{External criticism}

While the internal organisation of the practice and teaching of Chinese medicine might threaten its cohesion, external criticism can also destabilise it. A section of China's scientific community seems to have little time for it. In a shocking episode in 2006, Zhang Gongyao (张功耀), a professor at Zhongnan University (中南) at Changsha (长沙) in Hunan published an article calling for the abolition of Chinese medicine and pharmacology. ${ }^{(16)}$ His argument, going over ground already covered in some instances by modernist opponents of Chinese medicine at the start of the Republican era, made four points: much of Chinese medicine must be ranged alongside the quaint and the magical, its ways are less rational than that of biomedicine, it uses products drawn from endangered species, and many drugs are toxic. And the Xinhua News Agency put out an incisive article on 12 September 2006 pointing to the dangers of Chinese medicine, especially the toxicity of "natural remedies." Of course, the "opposing camp" reacted quickly (Xinhua, 19 October 2006); nevertheless, some of these criticisms did influence the course of Chinese medicine.

The toxicity of some traditional medicines, which has been taken into account throughout the long history of Chinese medicines, (17) has led to several debates over the past two decades, in China and elsewhere. In 1993, Belgian doctors identified a kind of vine, Aristolochia fangchi (广仿己 guangfangji), or more specifically, aristolochic acid - nephrotoxic and carcinogenic molecule - contained in this plant, as the source of serious nephropathy cases. This drug was part of the composition of a formula used in dieting regimes. ${ }^{(18)}$

In March 2003, a damages claim was lodged in a Chinese court against the Tongren Tang group ${ }^{(19)}$ by a patient suffering from uraemia, blamed on the consumption of the company's product "Gentian pill to drain the liver" (龙胆泻肝丸 - longdan xiegan wan). (20) The claim was rejected, as the consumer had to provide proof establishing the causality link. For a year, more such claims were lodged and met with similar dismissals. Be that as it may, this episode signalled a new awareness among Chinese consumers. As in the West, pharmaceutical products in general are regarded with mixed feelings of suspicion and expectation of effectiveness without side effects. Aristolochia manshuriensis was banned in April 2003 by the Guojia shipin yaopin jiandu guanli ju, while six other medicinal plants of the Aristolochia family were also banned in August 2004. (21)

This trend had consequences for research into Chinese medicine, which mainly tends to prove the innocuousness and effectiveness of traditional drugs. The 1998 administrative regulation of the National Bureau of Chinese Medicine and Pharmacology specified that research on Chinese medicine must be open to evaluation and verification following modern, precise scientific criteria. Most research projects in this domain focus on molecular pharmacology and the characterisation and extraction of active ingredients. For instance, in 2005, the Guojia ziran kexue jijin (国家自然科学基金 National Natural Science Foundation of China), which provides the most funds to the Chinese Academy of Medical Sciences, (22) backed 173 projects relating to Chinese medicine and pharmacology. Of these, 75 percent involved clinical observation of the treatment of a disease using a given pharmaceutical formula and the identification of active ingredients. In a way, such research could be carried out on any "traditional" medicine anywhere on earth, since the internal theoretical coherence of the medical system envisaged is ignored. (23)

\section{Intangible cultural heritage}

It was in this perpetually changing context that the issue of Chinese medicine's patrimonialisation emerged in the 2000s, echoing the theme of UNESCO's intangible cultural heritage (ICH). Following more

13. See the Chinese Pharmacopeia Commission's website (Guojia yaodian weiyuanhui 国家药典委员会), www.chp.org.cn (consulted on 23 November 2011), and Wang Li, "La Convention pour la sauvegarde du patrimoine culturel immatériel et son application en droits français et chinois," op. cit., p. 425 sq.

14. Volker Scheid, Contemporary Chinese Medicine, Plurality and Synthesis, op. cit., p. 171.

15. Wang Li, "La Convention pour la sauvegarde du patrimoine culturel immatériel et son application en droits français et chinois," op. cit., p. 411.

16. Zhang Gongyao, "Gaobie zhongyi zhongyao" (Taking leave of Chinese medicine and pharmacology), Ren yu yixue, no. 4, 2006.

17. Frédéric Obringer, L'Aconit et l'orpiment. Drogues et poisons en Chine ancienne et médiévale (Aconite and orpiment: Drugs and poisons ancient and medieval China), Paris, Fayard, 1997. The link between a substance's toxicity and its therapeutic effectiveness was made in ancient China itself, and the preparation of drugs has often sought to overcome potential dangers. But testing the effect of prescriptions, which combine several products, is much more difficult in view of possible interactions.

18. Maurice Vanhaelen, et al., "Identification of aristolochic acid in Chinese herbs," The Lancet, vol. 343, no. 8890, 1994, p. 174; also Minoru Okada, "Chinese herbs' nephropathy," The Lancet, vol. 354, 1999, p. 1732, which noted ten Japanese nephropathy cases in 1995 blamed on Aristolochia manshuriensis. It was claimed that the use of Aristolochia fangchi was due to an error, that it was confused with another plant, Stephania tetrandra (粉防己 - fenfangji). But this ignores basic ethnobotanic data. Classifications of plants in the Chinese bencao tradition or in the fangshu prescriptions do not follow Linnean classification. Many plants from different species or even families may be classed under the same Chinese name. Moreover, there is great variability of plants used in different provinces.

19. On this group, see infra.

20. The formula appeared for the first time in Lanshi micang (兰室秘藏) by Li Gao (李杲), published in 1336.

21. Wang Li, "La Convention pour la sauvegarde du patrimoine culturel immatériel et son application en droits français et chinois," op. cit., pp. 396-397.

22. Ibid., pp. 393-394.

23. On the issue of the pharmacopoeia's copyright, see Hong Jing (ed.), Zhongyao zhishi chanquan baohu (Intellectual property protection for Chinese pharmacopoeia), Beijing, Zhongguo zhongyiyao chubanshe, 2003. 
than ten years' reflection, the Convention on the Safeguarding of Intangible Cultural Heritage was adopted unanimously on 17 October 2003 by the UNESCO General Conference at its $32^{\text {nd }}$ session. It came into force on 20 April 2006. (24) As of August 2011, it had 137 states as parties.

"Intangible Cultural Heritage" is rendered in Chinese as fei wuzhi wenhua yichan (非物质文化遗产). ${ }^{25)}$ UNESCO offers the following definition, in which the importance attached to the notion of "communities" as custodians is worth noting:

The 'Intangible Cultural Heritage' means the practices, representations, expressions, knowledge, skills - as well as the instruments, objects, artefacts and cultural spaces associated therewith - that communities, groups and, in some cases, individuals recognize as part of their cultural heritage. This intangible cultural heritage, transmitted from generation to generation, is constantly recreated by communities and groups in response to their environment, their interaction with nature and their history, and provides them with a sense of identity and continuity, thus promoting respect for cultural diversity and human creativity.

The gradual development of the $\mathrm{ICH}$ concept can be traced back to the 1950s, when "folklore" was deemed to be in the public domain, not enjoying copyright protection. In 1973, Bolivia asked UNESCO to consider protecting folklore, the idea being that it could be in the state's domain. The 1982 World Conference on Cultural Policies in Mexico City agreed to treat cultural traditions the same as monuments. In 1989, the "Recommendation on the Safeguarding of Traditional Culture and Folklore" was adopted. Its main aim to promote studies on folklore and enhance skills, but the intellectual property aspect was ignored despite previous discussions with the World Intellectual Property Organisation (WIPO).

Attention then turned to the notion of intangible cultural heritage, in recognition of cultural practices and expressions not necessarily attached to a material form, object, frame, and so forth. It must be stressed that the 2003 Convention included so-called "elite" culture. ICH is thus not only "popular traditional culture." This must be borne in mind with regard to Chinese medicine, the fruit of scholarly work based on medical practices inherited from elites of yore.

Debates preceding the Convention's adoption were inspired by the desire to preserve what was initially called traditional and popular culture, which until the late 1980s meant research into "folklore." The growing feeling that globalisation was a threat to cultural diversity drew on previous experiences with the UNESCO lists of natural sites and monuments to forge the concept of "intangible cultural heritage."

The large number of activities that may be considered under ICH (oral traditions, performing art, social practices, rituals and festivals, the know-how needed for traditional crafts... ), (26) also included "knowledge and practices concerning nature and the universe":

This domain includes numerous areas such as traditional ecological wisdom, indigenous knowledge, knowledge about local fauna and flora, traditional healing systems, rituals, beliefs, initiatory rites, cosmologies, shamanism, possession rites, social organisations, festivals, languages and visual arts. (27)

\section{Categories of Intangible Cultural Heritage}

The 2003 Convention defined three major categories of $\mathrm{ICH}$ :

- Representative list of the intangible cultural heritage of humanity contains expressions demonstrating the diversity of intangible heritage in order to raise awareness of their importance. The intergovernmental committee overseeing ICH included 90 elements in 2008 (previously called "masterpieces") and 76 elements in 2009, adding 47 more in 2010.

- List of intangible heritage requiring urgent protection includes elements that communities concerned and states parties consider as necessitating urgent measures in order to ensure their transmission. Inclusion on this list helps mobilise international cooperation and assistance allowing stakeholders to take adequate protective measures. In 2009, the committee had included 12 elements, adding four more in 2010.

- Programmes, projects, and activities for safeguarding intangible cultural heritage. (28) The 2003 Convention also led to the "living human treasures" programme. These are "persons who possess to a high degree the knowledge and skills required for performing or recreating specific elements of the intangible cultural heritage." The programme was meant to encourage member states to accord official recognition to those carrying on a tradition and talented practitioners, as well as to ensure transmission of their know-how to younger generations. The "living human treasures" must be compared with the Chinese "representative transmitter" (传承人 chuancheng ren) discussed earlier.

\section{China and ICH}

The notion of "heritage" does not have the same history in the West and China. It may be said that Western thought favoured material and monumental aspects of heritage. In Chinese thinking, the authentic search should go beyond the material and seek out know-how and ability. ${ }^{(29)}$ This assertion is to be seen in perspective: the emergence of the concept of intangible cultural heritage found great favour in China, which became a state party to UNESCO's ICH Convention in August 2004. ${ }^{\left({ }^{30}\right)} \mathrm{A}$ programme

24. On intangible cultural heritage, see www.unesco.org/new/en/culture (consulted on 23 November 2011), containing several documents online; "Patrimoine culturel immatériel, les enjeux, les problématiques, les pratiques" (Intangible cultural heritage: challenges, problems practices), Internationale de l'imaginaire, N.S., no. 17, Maison des cultures du monde, Babel, January 2004; Richard Kurin, "La sauvegarde du patrimoine culturel immatériel selon la Convention de l'Unesco de 2003, une évaluation critique" (Safeguarding intangible cultural heritage according to the 2003 Unesco Convention, a critical evaluation), Museum international, vol. 56, no. 221-222, 2004, pp. 68-78; "Le patrimoine culturel immatériel à la lumière de l'Extrême-Orient" (Intangible cultural heritage, in the Far East perspective), Internationale de l'imaginaire, N.S., no. 24, Maison des cultures du monde, Babel, June 2009; Wang Li, "La Convention pour la sauvegarde du patrimoine culturel immatériel et son application en droits français et chinois," op. cit.

25. For China, see the official site: www.ihchina.cn (consulted on 23 November 2011); Zhang Liang, La naissance du concept de patrimoine en Chine, XIXe-XXe siècle (Birth of the heritage concept in China...), Paris, ed. Recherches/lpraus, 2003.

26. Kit of the Convention for the Safeguarding of the Intangible Cultural Heritage: www.unesco.org/ culture/ich/?pg=00252 (consulted on 23 November 2011).

27. Safeguarding Intangible Cultural Heritage, UNESCO, p. 56, www.unesco.org/culture/ich/?pg=56 (consulted on 23 November 2011).

28. See www.unesco.org/culture/ich/index.php?lg=EN\&pg=home (consulted on 23 November 2011).

29. Jocelyne Fresnais, La protection du patrimoine en République populaire de Chine (1949-1999) (Heritage protection in the PRC), Paris, éd. du CTHS, 2001; Zhang Liang, La naissance du concept de patrimoine en Chine, XIXe-XXe siècle, op. cit, Chen Feilong, "La sauvegarde du patrimoine culturel immatériel en Chine" (Protecting intangible cultural heritage in China), in "Le patrimoine culturel immatériel à la lumière de l'Extrême-Orient" (Intangible cultural heritage protection with a Farest orientation), Internationale de l'imaginaire, N.S., no. 24, Maison des cultures du monde, Babel, 2009, pp. 49-63; Wang Li, "La Convention pour la sauvegarde du patrimoine culturel immatériel et son application en droits français et chinois," op. cit.

30. The official site (http://www.hihchina.cn) contains abundant information and links. 
to protect "China's national and popular culture" was launched in early 2003 by the Ministry of Culture, the Ministry of Finance, the Commission of Nationalities, and Cultural Federations. ${ }^{(31)}$ From 2004, a vast inventory work was undertaken, leading to the first official listing of China's national heritage in 2006 (518 elements), then the second in 2008 (510 elements), and a third in 2011 (191 elements); in all, 1,219 elements have been recognised thus far. ${ }^{(32)}$ Apart from drawing up lists and taking actions, such as declaring a Cultural Heritage Day and holding numerous exhibitions, the authorities also chose cultural heritage "inheritors," that is, living treasures, keeping in mind transmission of know-how. A first list contained 226 in 2007, and a second had 551 in 2008. (33)

Among the elements included in China's list of intangible cultural heritage, many pertain to Chinese medicine. They will be examined in greater detail.

\section{Chinese medicine in the national lists of $\mathrm{ICH}$}

\section{The 2006 list}

The first national heritage list in 2006 (国家名录 - Guojia minglu) contained nine elements from the medical domain. The nominations presented are accessible, with Chinese and English versions. (34) In general, the Chinese nominations are detailed and expanded, mentioning the title of the medical works, but these are ignored in the English version, which is clearly meant for an international public deemed almost totally ignorant of China's history and its medicinal systems. We will consider nine of these elements:

\section{TCM approach to life and to disease}

In Chinese it is Zhongyi shengming yu jibing renzhi fangfa (中医生命与疾 病认知方法 ) and in English "The perception method of life and disease of TCM." The stakeholder is the Chinese Academy of Medical Sciences.

Recalling that Traditional Chinese Medicine (TCM in English while in Chinese the text merely says zhongyi) has a more than 2,000 years' history, the text sets out in highly simplified terms the conception of disease, noting basic elements of what may be called Chinese "correlative thinking": the Yin-Yang imbalance that lies behind health problems. The causative role of wuxing 五行 ("five agents," wood, fire, earth, metal, and water) are set out:

TCM uses a system of inter-relationships between the five elements to understand how the various processes of the body support and control each other. Because of these inter-relationships, when one of the organs and its associated element is out of balance, the other elements are also affected.

The text then quickly goes over the " wuyun liuqi 五运六气," a system that was highly influential during the Song dynasty. ${ }^{(35)}$

The theory of directing one's strength focuses on how various components such as astronomy, meteorological phenomena, and climate would affect health. This theory consists of two parts, five strengths, and six climatic factors.

Then the zang 脏 (spleen, heart, lungs, liver, and kidneys) and fu 腑 (small intestine, large intestine, gall bladder, bladder, stomach, and san jiao 三角 "Triple Burner", an invisible metabolising organ in TCM concept) are cited, with the following explanation:
Each organ is considered to have its own functions, but these functions have a far wider scope than the purely physiological function described in Western medicine.

While this assertion is not in the nature of evidence, it is one of the topoi regularly used to explain the different ways of seeing the role of organs in Chinese and Western medicine. As enunciated here, it would suffice to say that they cannot be understood because they are insufficiently developed. Another explanation is given for the triple burner, an organ whose definition has been debated throughout Chinese history: "A three-part invisible metabolising organ in TCM concept." Clearly, this refers to a "formless" (无 形 - wuxing) organ, (36) one of two conceptions (the other being that sanjiao "has form") of this organ. Attention must be paid in this definition to the term "metabolising," the scientific connotation of which lends modernist garb to Chinese medical thinking. The use of the word "metabolism" began as recently as the 1860 s $^{(37)}$ with the development of biochemistry. At any rate, the term's use is not insignificant.

After a brief introduction to the role of "meridians," the text ends by hinting at Chinese medicine's precarious position:

\section{But because of the influence of Western medicine, there are fewer} people who understand and can pass on this knowledge system. Therefore, it is in great need of protection and development.

This clearly puts Chinese medicine in a position requiring protective measures in view of the growing dominance of Western medicine.

\section{Chinese medicine's diagnostic methods.}

The Chinese title is Zhongyi zhenfa (中医诊法) and in English "Diagnostic Methods of Chinese Medicine." The stakeholder is again the Chinese Academy of Medical Sciences.

A quick look at the Chinese medicinal system's four major diagnostic methods (四诊 - sizhen) follows: observation (望 - wang), auscultation and olfaction (闻 - wen ), interrogation (问 - wen), and pulse-taking and palpation (切 - qie). The main difference between the Chinese and English versions is that the Chinese one mentions the major texts dealing with the subject, such as Maijing (脉经 - Pulse Classic) by Wang Shuhe (王叔和) from the third century AD (late Han dynasty). The mention of such works in the Chinese version lends a historic depth lacking in the English one.

\section{Techniques of preparing Chinese medical material}

In Chinese it is Zhongyao paozhi jishu (中药炮制技术), and in English "Technology of processing Chinese materia medica." The stakeholders are the Chinese Academy of Medical Sciences and the China Association of Traditional Chinese Medicine (中国中药协会 - Zhongguo zhongyao xiehui).

31. Chen Feilong, "La sauvegarde du patrimoine culturel immatériel en Chine," op. cit., p. 50.

32. Xinhua, 10 June 2011.

33. Chen Feilong, "La sauvegarde du patrimoine culturel immatériel en Chine," op. cit., p. 57.

34. www.chinaheritagenewsletter.org/007/features/501_firstlist.pdf (consulted on 23 November 2011).

35. Catherine Despeux, "The system of the five circulatory phases and the six seasonal influences (wuyun liuqi), a source of innovation in medicine under the Song (960-1279)," in Elisabeth Hsu (ed.), Innovation in Chinese Medicine, Cambridge, Cambridge University Press, 2001, pp. 121-165.

36. Wang Xinhua (ed.), Zhongyi jichu lilun, Pékin, Renmin weisheng chubanshe, 2001, pp. 238-243.

38. See Sherman Cochran, Chinese Medicine Men: Consumer Culture in China and Southeast Asia, Harvard, Harvard University Press, 2006, pp. 19 sq. 
The element is quickly presented:

Processing Chinese materia medica means using traditional methods and technology to create herbal medicine slices. After processing, the medical effects of the medication are improved and the side effects decrease. Processing is a necessary procedure.

Then follows a succinct narration of the history of drug preparation techniques. The English version merely cites Shennong bencao jing (神农本草经 - The Divine Farmer's Herb-Root Classic), from about the first century AD, and the Bencao gangmu (本草纲目 - Compendium of Materia Medica) by Li Shizhen (李时珍 1596), while the Chinese one mentions the great classic Leigong paozhi lun (雷公炮炎论 - Leigong's Treatise on Drug Preparation), a series of texts dating from the fifth century to the Song dynasty. It ends with a mention of the highly worrying situation as regards drug preparation know-how:

At present, there are only about 100 people working on processing materia medica, and the technology is in danger of dying out. Furthermore, some departments haven't paid enough attention to traditional processing technology or taken protective measures. Therefore, the technology of processing Chinese materia medica is in great need of protection.

Under these conditions, it seemed imperative to submit the nominations to UNESCO as elements to be included on the ICH list needing urgent protection.

\section{Traditional galenic preparation methods in Chinese medicine}

The Chinese title is Zhongyi chuantong zhiji fangfa (中医传统制剂方法), and in English, "The traditional preparation method of Chinese medicine." The stakeholders are the Chinese Academy of Medical Sciences and the China Association of Traditional Chinese Medicine.

Most succinctly, the text presents the main galenic forms used in Chinese medicine: pills (丸 - wan and 丹 - dan), powders (散 - san), pomades (膏 - gao), and decoctions (汤 - tang). It is worth noting the hoary antiquity (Shang dynasty or earlier) of some modes of drug preparation, especially of 药酒 - yaojiu, rendered in English as "medicated alcohol," the "alcohol" there being rather anachronistic.

\section{Acupuncture and moxibustion.}

Zhenjiu (针炎) in Chinese is rendered in English as "acupuncture." The stakeholders are the Chinese Academy of Medical Sciences and the China Association of Acupuncture and Moxibustion (中国针炎学会 - Zhongguo zhenjiuxue hui).

The English text begins with an assertion in an apparent quest for legitimation in the eyes of international observers:

Acupuncture is an important part of Chinese medicine. It was initially invented as a technique of medical treatment and gradually became a science.

Following a brief introduction, the text contains a part on acupuncture's history and another on Zhenjiu jiayi jing (针炎甲乙经) by Huangfu Mi (with a vulgar error in the English text, "Huang Fumi") 皇甫监 (214-282). The text later led to a more detailed version that helped include acupuncture in UNESCO's list in 2010.

\section{Techniques for healing fractures in Chinese medicine}

Zhongyi zhenggu liaofa (中医正骨疗法) is given as "Chinese medicine bonesetting techniques" in English. The stakeholder is the Chinese Academy of Medical Sciences.

The short (eight-line) English text notes that accounts existed in antiquity relating to healing bone fractures and use of splints. The use of small splints (小夹板 - xiaojiaban) is presented as China's contribution to global medicine. The text stresses that such methods are disappearing for economic reasons; the slightly longer Chinese text specifies that such techniques are only to be found in ten or so Chinese medicine hospitals.

\section{Medicinal culture of the Tongren tang Chinese pharmacy}

Tongren tang zhongyiyao wenhua (同仁堂中医药文化): In English, "Culture of the Tong Ren Tang Drugstore." The stakeholder is the Tongren Tang company.

The text briefly introduces the famous pharmacy and its products. Tongren Tang's history is noteworthy. Founded in Beijing by Yue Xianyang (乐 显扬) in 1669, the pharmacy gradually emerged as a veritable industrial enterprise and is one of the most prestigious instances of pharmacy's importance in Chinese medicine. It also illustrates the success of a commercial development strategy that was able to draw on close connections to the central authorities.

It was Yue Fengming (乐风鸣), son of Yue Xianyang, who opened the first shop in 1702, near Qianmen (前门) at Dashalan (大棚栏), a commercial district known to be closest to the imperial court. Yue Fengming secured a medical official's post and in 1723 became the designated supplier of medicines to the court. Tongren Tang's history is in some ways the story of commercial success shrewdly pursued through imperial patronage. Fires ravaged the pharmacy in 1753 and 1834, but the firm prospered nevertheless: by the late Qing it sought to guard against rivals' machinations and by investing in charitable works. In the twentieth century, 34 other pharmacies with the Tongren Tang brand name opened between 1907 and 1949, all following the traditional model and not imitating the Western style. In this sense, Tongren Tang symbolises pharmaceuticals "à la chinoise." (38)

\section{Medicinal Culture Huqingyu tang Chinese pharmacy}

Huqingyu tang zhongyao wenhua (胡庆余堂中药文化): in English, "Culture of the Hu Qing Yu Tang Drugstore." The stakeholder is the Huqingyu Tang Chinese Medicine Museum.

Huqingyu ${ }^{(39)}$ was formed in Hangzhou in 1874 by Hu Xueyan (胡雪岩 1823-1885), one of the most famous Chinese businessmen in the late Qing period. Hu was close to Zuo Zongtang (左宗棠 1812-1885), a military chief and administrator who took part in quelling the Taiping rebellion and founded the Fuzhou arsenal (1866). ${ }^{(40)}$ While he was engaged in the

39. For a brief account of Huqingyu, see http://fy.folkw.com/view.asp?id=483 (consulted on 23 November 2011).

40. See Jacques Gernet, Le monde chinois (The Chinese world), Paris, Armand Colin, 1999, p. 483.

41. For a good introduction to Tibetan medicine, see Fernand Meyer, Gso-ba rig-pa: Le système médical tibétain (Tibetan Medical System), Paris, Éditions du CNRS, 1981. 
silk and tea trade among other activities, Hu Xueyan also produced pharmaceuticals, which gave rise to the name Huqingyu (in which qingyu invokes yuqing 余庆, the "joy inherited from virtuous parents"). The beautiful commercial building that housed the pharmacy was turned into a Chinese medicine and pharmacopeia museum in 1991.

Both the English and Chinese texts note that Huqingyu pharmacy, or rather Hu Xueyan himself, had a commercial attitude based on jieqi (戒欺 - avoiding deception). It would seem that the stress on such moral rectitude in business could have contemporary echoes.

\section{Tibetan medicine}

In Chinese it is Zang yiyao (藏医药) and in English "Tibetan medicine and pharmacopoeia." The stakeholders are: Lhasa's northern school of Tibetan medicine's mercury cleansing and refining techniques, and Tibetan pharmacopoeia and herbal preparation techniques of Renqen Changjor, Garzê prefecture's southern school of Tibetan medicine and pharmacopoeia.

The rather long text includes a general introduction beginning thus:

Tibetan medicine, one of the world's oldest ancient medical systems that began over 2300 years ago, is a mix of science, art, and philosophy that takes a holistic approach to health care.

Reading the rest of the text, it is difficult to make out Tibetan medicine's development. Tibetan medicine's basic work, Rgyud-bzhi ("Four Treatises"), is mentioned only in passing and in the last paragraph, after examining the North and South Schools. As is well known, Tibetan medicine is made up of the double influence of India's Ayurveda and Chinese medicine, something the text totally ignores. ${ }^{(41)}$ The Chinese version is presented in a much different way and highlights techniques of mercury processing in Tibetan medicine.

This is not the place to consider political issues regarding Tibet and China, but it seems rather improbable that Tibetan medicine would be submitted to UNESCO for inclusion as an $\mathrm{ICH}$.

\section{The 2008 and 2011 lists}

The 2008 national heritage list has eight elements from the medical domain: ${ }^{(42)}$

1. Preparations for "life cultivation" in Chinese medicine (中医养生 Zhongyi yangsheng).

2. Medicinal culture and traditional Chinese pharmacology (传统中医药 文化 - chuantong zhongyiyao wenhua): texts offered by pharmacies and pharmaceutical firms.

3. Mongolian medicine and pharmacology (蒙医药 - Meng yiyao).

4. She nationality medicine and pharmacology (會族医药 - Shezu yiyao). The She are a minority nationality in Zhejiang and Fujian.

5. Yao nationality medicine and pharmacology (瑶族医药 - Yaozu yiyao). The Yao are a minority nationality in Guizhou.

6. Miao nationality medicine and pharmacology (苗医药 - Miao yiyao). The Miao are a minority nationality (Hmong) in southern China's mountainous areas.

7. Dong medicine and pharmacology (侗医药 - Dong yiyao). The Dong are a minority nationality in Yunnan.

8. Hui medicine and pharmacology (回族医药 - Huizu yiyao). The Hui are a Muslim minority. ${ }^{(43)}$
Finally, the third list in $2011^{(44)}$ included one item: Medicine and pharmacology of the Dai (傣医药 - Dai yiyao), a minority nationality in Yunnan. As is clear, these primarily concern minority nationalities' medicinal practices.

\section{Inclusion of acupuncture and moxibustion in the 2010 ICH list}

UNESCO's Intergovernmental Committee for the Safeguarding of the Intangible Cultural Heritage met from 15 to 19 November 2010 in Nairobi, Kenya. ${ }^{(45)}$ In China's case, it decided to include three items on the List of Intangible Cultural Heritage in Need of Urgent Safeguarding:

- Wooden movable type printing;

- Meshrep; ${ }^{(46)}$

- The watertight-bulkhead technology of Chinese junks.

The committee also decided to include two elements on the Representative List of the Intangible Cultural Heritage of Humanity:

- Acupuncture and moxibustion in Chinese traditional medicine;

- Peking opera.

- On acupuncture and moxibustion in Traditional Chinese Medicine, the UNESCO site said: ${ }^{(47)}$

Acupuncture and moxibustion are forms of traditional Chinese medicine widely practised in China and also found in regions of south-east Asia, Europe and the Americas. The theories of acupuncture and moxibustion hold that the human body acts as a small universe connected by channels, and that by physically stimulating these channels the practitioner can promote the human body's selfregulating functions and bring health to the patient. This stimulation involves the burning of moxa (mugwort) or the insertion of needles into points on these channels, with the aim to restore the body's balance and prevent and treat disease. In acupuncture, needles are selected according to the individual condition and used to puncture and stimulate the chosen points. Moxibustion is usually divided into direct and indirect moxibustion, in which either moxa cones are placed directly on points or moxa sticks are held and kept at some distance from the body surface to warm the chosen area. Moxa cones and sticks are made of dried mugwort leaves. Acupuncture and moxibustion are taught through verbal instruction and demonstration, transmitted through master-disciple relations or through members of a clan. Currently, acupuncture and moxibustion are also transmitted through formal academic education.

42. See www.ihchina.cn (consulted on 23 November 2011).

43. On the Hui, see Elisabeth Allès, Musulmans de Chine, Une anthropologie des Hui du Henan (Muslims in China: An anthropology of the Hui of Henan), Paris, EHESS, 2000.

44. Xinhua, 10 June 2011.

45. See www.unesco.org/culture/ich/index.php?lg=en\&pg=00272 (consulted on 23 November 2011).

46. Traditional autumnal gathering in Uyghur regions and Central Asia, featuring music, dance and poetry.

47. See www.unesco.org/culture/ich/index.php?lg=en\&pg=00011\&RL=00425 (consulted on 23 November 2011).

48. Submission text no. 00425 , p. 8; available online, www.unesco.org/culture/ich/doc/download.php? versionlD=07331 (consulted on 23 November 2011). 
Many points are worth noting in the above. First, it is striking that acupuncture and moxibustion are now being practiced outside China, contributing to the circulation of know-how in these globalising times. This international legitimation perhaps has a strategic value for TCM proponents in China itself, as the discipline's internal situation sometimes puts it in a vulnerable state, as noted earlier. Second, it should be noted that a holistic representation of the human body is attributed to acupuncture and moxibustion. This would automatically place it in the "complementary medicine" category, which confronts the dominant biomedicine model globally. Finally, the issue of transmission is stressed, in particular the "master-disciple" model. This links the debates discussed above to the issue of Chinese medicine's "standardisation" to university teaching.

UNESCO's site also offers a diaporama and a video, as well as a submission form in English and French, the consent of communities in Chinese and English, and the decision regarding inclusion in the $\mathrm{ICH}$ list. It is interesting that the "Consent of communities" document carries the following doctors' signatures: ${ }^{(48)}$

He Puren (贺普仁 1926-) ) $^{(49)}$ was professor of acupuncture and moxibustion at the TCM hospital in Beijing. The author of numerous books and a specialist in acupuncture linked to the "eight trigrams" (八卦 - bagua) of Yijing, He is introduced as "representative successors of acupuncture and moxibustion" in Traditional Chinese Medicine.

Wang Xuetai (王雪苔 1925-2008), Honorary president of the World Federation of Acupuncture and Moxibustion Societies. ${ }^{(50)}$

Cheng Xinnong (程莘农 1921-), "representative successor" and "senior expert on Chinese medicine," established successors' workshops in 2007 and took on 25 apprentices. The National Medical Master Cheng Xinnong Academic Seminar was held in 2009. ${ }^{(51)}$ Chen is vice-president of the China Association of Acupuncture and Moxibustion (中国针炎学会 Zhongguo zhenjiuxue hui) and author of Zhongguo zhenjiuxue (中国针炎 学), or Chinese Acupuncture and Moxibustion in English. ${ }^{(52)}$

Zhang Jin (张缙 1930-) is introduced as supervisor and professor for academic successors of famous and venerable doctors of Chinese traditional medicine.

It is still too early to grasp the precise contribution that could follow from the inclusion of acupuncture and moxibustion on the ICH list. Any inclusion implies protective measures submitted in the candidature text. As for the element discussed here, measures for knowledge transmission and documentation have been described and budgeted, as UNESCO will provide funding. ${ }^{(53)}$ Be that as it may, Chinese medicine's quest for heritage status may be seen as a defensive reaction to attacks been directed at it for nearly a century and also as a response to an objective situation in which it has been losing ground in China's health landscape. One of the most insidious dangers for Chinese medicine stems from its having to don the garb of other medical practices known to be more "scientific," such as biomedicine, in order to preserve itself without losing its soul. But responding to the heritage enticement has larger consequences, leading to Chinese medicine's emergence as humanity's "common good." As André Chastel has said: "By disrupting and breaking age-old practices, the global trading and industrial civilisation helps discover their qualities, which are quickly classed, rightly or wrongly, in the heritage pantheon." (54)

\section{Translated by N. Jayaram}

\footnotetext{
49. www.cintcm.ac.cn/zyzl/hpr-e.html (consulted on 23 November 2011).

50. http://news.sciencenet.cn (consulted on 23 November 2011).

51. Submission text no. 00425

52. Chen Xinnong, Chinese Acupuncture and Moxibustion, Foreign Languages Press, 1985, $3^{\text {rd }}$ edition, 2010.

53. Submission text, p. 7, available online, www.unesco.org/new/en/culture (consulted on 23 November 2011).

54. André Chastel, "La notion de patrimoine" (The heritage notion), in Pierre Nora (ed.), Les lieux de mé-
} moire, (Remembered places) tome 1, Paris, Gallimard, col. "Quarto," 1997, p. 1465. 